\title{
Lemon Pepper Extract Improves Diabetic Nephropathy in Diabetic Rats
}

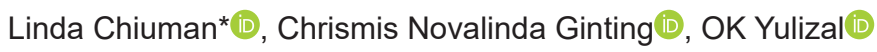 \\ Department of Histology, Faculty of Medicine, Universitas Prima Indonesia, Medan, North Sumatera, Indonesia
}

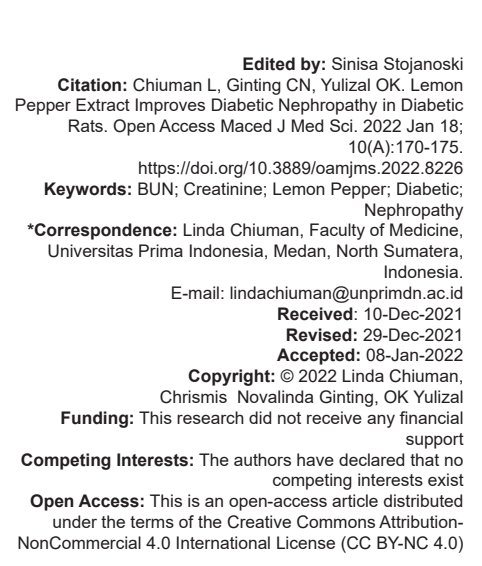

\begin{abstract}
BACKGROUND: Prolonged uncontrol non-insulin dependent diabetes mellitus (NIDDM) leads to various complications. One of these complications is diabetic nephropathy. Around $24 \%$ of the US population suffered from diabetes between 2009 and 2014 , and $25 \%$ suffered from chronic kidney disease. Lemon pepper fruit may become an alternative treatment from a natural product to prevent kidney damage in diabetic conditions.

AIM: The aim of the study was to investigate the kidney protection effect of lemon pepper extract in streptozotocininduced Wistar rats with diabetic nephropathy.

METHODS: This experimental study used 25 male Wistar rats grouped into five different groups. These groups were standard, control, lemon pepper ethanol extract (LPEE)-I, II, and III that were received Metformin, $0.5 \% \mathrm{Na}-\mathrm{CMC}$ and lemon pepper ethanol extract at the dose of 500,750 , and $1000 \mathrm{mg} / \mathrm{kg} \mathrm{BW}$, respectively.

RESULTS: The intervention was performed for 14 days. The result showed that the standard, control, lemon pepper ethanol extract (LPEE)-I, II, and III significantly decreased the BUN (Blood urea nitrogen) and reatinine level $(p<0.05)$. Moreover, the histology study also showed some improvement of like preserved tubular and glomerular from necrosis.

CONCLUSION: The highest lemon pepper ethanol extract dose significantly decreased the BUN $(23.08 \%)$ and creatinine $(59.49 \%)$ levels.
\end{abstract}

\section{Introduction}

Diabetes mellitus is defined by the World Health Organization (WHO) as a chronic condition caused by either the inadequate use of insulin in the body or the failure to secrete insulin. Moreover, American Diabetic Association (ADA) classified diabetes as insulin dependent diabetes mellitus (IDDM), non-insulin dependent diabetes mellitus (NIDDM), gestational diabetes, and other types of diabetes (like late onset diabetes autoimmune/LADA or maturity onset diabetes of young/MODY) [1], [2].

NIDDM is quite common in many regions of the world. According to the International Diabetes Federation (IDF), the global prevalence of diabetes was $8.3 \%$ (about 387 million people) in 2014. Indonesia ranked $7^{\text {th }}$ as the highest diabetes case after China, India, the USA, Brazil, Russia, and Mexico. Moreover, Perhimpunan Endokrinologi Indonesia [Association of Indonesia Endocrinologists] (PERKENI) also described local data. PERKENI reported that 9.1 million people were suffering from NIDDM in 2015. Other data documented by the Health Ministry also reported the prevalence of NIDDM in 2018 in basic health research (Riset Kesehatan Dasar) [3], [4].
Prolonged uncontrol NIDDM leads to various complications that are microvascular and macrovascular. Insulin resistance causes a macrovascular complication, while chronic hyperglycemia causes microvascular complications. The basic mechanism of these complications was glycolysis that caused oxidative stress. The oxidative stress destructs blood vessels wall that induces releasing of various inflammation mediators such as endothelin-A, thromboxane-A2, prostacyclin, and nitrate oxide (NO); these mediators increase the vascular tone and maintenance homeostasis between coagulation and fibrinolysis. Both endothelin-A and thromboxane-A2 induce vasoconstriction. Meanwhile, prostacyclin and nitrate oxide (NO) induce vasodilation [5].

There are various microvascular complications in diabetic patients; however, one is diabetic nephropathy. In histology study, diabetic nephropathy was shown as thickening of glomerular basal membrane, mesangial sclerosis, nodular glomerulosclerosis (Kimmelstiel-Wilson nodules), and accumulation of non-specific IgG in immunohistochemical staining [6]. Around $50 \%$ of end-stage kidney failure was caused by diabetic nephropathy. Around $24 \%$ of the US population suffered from diabetes between 2009 and 2014 and $25 \%$ suffered from chronic kidney disease. 
Due to these reasons, it becomes important to look for an alternative therapy to treat diabetes patients and prevent diabetic nephropathy that ends as a kidney failure. Herbs promote alternatives for diabetic treatment; one of these herbs was lemon pepper fruit, also known as andaliman, widely used in Batak Community. Some studies have looked for pharmacology effects from lemon pepper fruit such as anti-inflammatory, antioxidant, anti-diabetic, and antibacterial [7], [8], [9], [10]. These pharmacology effects are associated with phytochemical contents such as phenol, saponin, flavonoid, triterpenoid, and alkaloid [11].

Some previous studies have been looked for anti-diabetic effects of lemon pepper. Worotikon et al. (2017) reported that lemon pepper ethanol extract had an anti-diabetic effect at a dose of $150-300 \mathrm{mg} / \mathrm{kg} \mathrm{BW}$ in alloxan-induced diabetes; interestingly, this extract also had an effect protecting the kidney structure. Moreover, Ridho and Londarto (2017) also reported that lemon pepper extract significantly decreased blood glucose level at the dose of $300 \mathrm{mg} / \mathrm{kg} \mathrm{BW}$ in insulindependent diabetes mice [7], [12]

Some previous studies have looked for the kidney protection effects of lemon pepper extract. These previous studies only investigated kidney histology with narrative description in alloxan-induced rats. Thus, this study investigated the kidney protection effect by more complex parameters, namely, histology study with EGTI scoring system and kidney function test for supporting the histology study. Based on the information above, this study was aimed to investigate the kidney protection effect of lemon pepper ethanol extract in streptozotocininduced Wistar rats with diabetic nephropathy.

\section{Methods}

\section{Study design}

This study was an experimental study that used a post-test-only group control design that was performed in August 2021 in Pharmacology Laboratory, Universitas Prima, Indonesia. All procedures have been approved by Health Research Ethics Committee from Universitas Prima, Indonesia with letter no. 009/KEPK/ UNPRI/VIII/2021.

\section{Extraction process}

This study used some lemon pepper fruits from a traditional market in Medan, North Sumatera. These lemon pepper fruits were identified in Herbarium Medanense, Faculty of Mathematics and Sciences, Universitas Sumatera Utara. All identified lemon pepper fruits were washed and dried; these were meshed to form a simplicial powder. Then, this simplicial powder was extracted by maceration methods soaked into proanalysis ethanol solvent for 3 days and filtered. The residue was extracted again, in the same way, 2 times. Meanwhile, these filtrates were collected to evaporate by rotary evaporator at $50^{\circ} \mathrm{C}$ until concentrated [13].

\section{Phytochemical screening}

The lemon pepper ethanol extract underwent phytochemical screening based on Fransworth methods described by Salim et al. (2021). Moreover, this phytochemical screening was looked for alkaloid, saponin, flavonoid, tannin, steroid, and terpenoid [13], [14].

\section{Preparation of oral solution and suspension}

This study used streptozotocin solution to induce diabetic nephropathy. Streptozotocin powder was dissolved into $0.01 \mathrm{M}$ buffer citrate to form a $5 \mathrm{mg} /$ $\mathrm{ml}$ streptozotocin solution by the volumetric flask. On the other hand, this study also used oral suspension for extract and standard drugs. The oral suspension was made of sodium carboxymethyl cellulose (CMC-Na). Amount of $3 \mathrm{~g} \mathrm{CMC-Na}$ powder was dissolved into $50 \mathrm{ml}$ distilled water to form $0.5 \%$ CMC-Na. After that, $500 \mathrm{mg}, 750 \mathrm{mg}$, and $1000 \mathrm{mg}$ of lemon pepper ethanol extract were suspended into $100 \mathrm{ml}$ of $0.5 \%$ CMC-Na suspension to form lemon pepper ethanol extract (LPEE) suspension dose of $500 \mathrm{mg} / \mathrm{kg} \mathrm{BW}, 750 \mathrm{mg} / \mathrm{kg} \mathrm{BW}$, and $1000 \mathrm{mg} / \mathrm{kg} \mathrm{BW}$, respectively. Moreover, this study also used Metformin as the standard drug. Amount of $500 \mathrm{mg}$ Metformin was grounded, and then it was suspended into $25 \mathrm{ml}$ of $0.5 \%$ CMC-Na suspension to form Metformin suspension [15], [16].

\section{Intervention}

This study used 25 male Wistar rats weighing 180-225 g; these rats were determined based on Federer formulation. In the beginning, blood glucose levels from all rats were measured by a glucometer and these blood glucose levels must be lower than $200 \mathrm{mg} / \mathrm{dl}$ to include in this study. These rats were grouped into five groups that were standard, control, and lemon pepper ethanol extract (LPEE)-I, II, and III [17], [18].
a. Standard: All rats received a milliliter of Metformin suspension (100 mg/kg BW) by oral gavage.
b. Control: All rats received a milliliter of $0.5 \%$ CMC-Na by oral gavage.
c. LPEE-I: All rats received a milliliter of LPEE Suspension dose of $500 \mathrm{mg} / \mathrm{kg} \mathrm{BW}$ by oral gavage
d. LPEE-II: All rats received a milliliter of LPEE suspension dose of $750 \mathrm{mg} / \mathrm{kg} \mathrm{BW}$ by oral 


\section{gavage.}

e. LPEE-III: All rats received a milliliter of LPEE suspension dose of $1000 \mathrm{mg} / \mathrm{kg} \mathrm{BW}$ by oral gavage.

All rats freely accessed food and beverages. These interventions were performed for 14 days. After that, all rats were measured their blood glucose level and sacrificed by chloroform inhalation in a closed room. Then, these rats were fixed into paraffin block and vertically incised from thorax to abdomen to obtain kidney and blood. The kidney was obtained by dissecting the kidney in the retroperitoneal space. Meanwhile, the blood was obtained by cardiac puncture [14].

Obtained kidneys were processed for histology study. All dissected kidneys were preserved in the $10 \%$ buffer formalin solution (BFS) until these kidneys were used. Furthermore, these kidneys were sliced with 4-6 $\mathrm{mm}$ thickness. After that, these slices were stained by hematoxylin and eosin (H\&E) and observed under a microscope. The obtained blood from cardiac puncture was collected into a red-colored blood tube. After that, these blood tubes were centrifuged at $3000 \mathrm{rpm}$ for $15 \mathrm{~min}$ to obtain serum at the upper layer. Moreover, this serum was measured blood urea nitrogen (BUN) and creatinine level by enzymatic reaction methods in the local laboratory (Laboratorium Kesehatan Daerah Sumatera Utara) [14].

All data were analyzed by descriptive statistics, central tendency, and dispersion. After that, oneway ANOVA analyzed BUN and creatinine, followed by post hoc Tukey HSD. Meanwhile, the histology of kidney tissue was narratively described.

\section{Results}

Identification of lemon pepper fruit showed that the kingdom, division, class, ordo, family, genus, and species were Plantae, spermatophyte, Dicotyledonae, Sapindales, Rutaceae, Zanthoxylum, and Zanthoxylum acanthopodium. Moreover, the obtained lemon pepper ethanol extract contained some phytochemicals, namely, alkaloid, saponin, flavonoid, tannin, steroid, and terpenoid. Furthermore, this study also evaluated the kidney protection effect from lemon pepper ethanol extract against diabetic nephropathy described in Table 1.

Based on Table 1, there is a significant difference in BUN and creatinine level in all groups, and

Table 1: Comparison of BUN and creatinine level in all groups

\begin{tabular}{lll}
\hline Groups & \multicolumn{2}{l}{ Kidney function test, Mean \pm SD } \\
\cline { 2 - 3 } & BUN $(\mathrm{mg} / \mathrm{dL})$ & Creatinine $(\mathrm{mg} / \mathrm{dL})$ \\
\hline Control & $67.60 \pm 3.44^{\mathrm{a}}$ & $0.79 \pm 0.12^{\mathrm{a}}$ \\
Standard & $42.40 \pm 1.14^{\mathrm{b}}$ & $0.24 \pm 0.02^{\mathrm{b}}$ \\
LPEE-I & $64.40 \pm 1.14^{\mathrm{a}}$ & $0.48 \pm 0.04^{\mathrm{c}}$ \\
LPEE-II & $55.80 \pm 0.84^{\mathrm{c}}$ & $0.37 \pm 0.01 \mathrm{c},{ }^{\mathrm{d}}$ \\
LPEE-III & $52.00 \pm 0.71^{\mathrm{d}}$ & $0.32 \pm 0.01 \mathrm{~b},{ }^{\mathrm{d}}$ \\
p-value & $<0.05$ & $<0.05$ \\
\hline p-value was obtained from one-way ANOVA; Different superscript in the same column showed a significant
\end{tabular}

difference according to the post hoc test Tukey HSD. it can be seen from $\mathrm{p}<0.05$. The post hoc test Tukey HSD showed that the BUN level in all groups significantly differed. However, the creatinine level showed a different pattern. The creatinine level from the standard group did not show any significant differences against the LPEE-III.

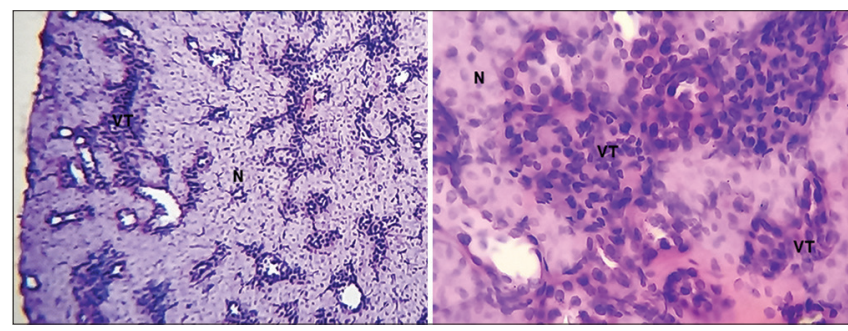

Figure 1: Light Micrographs of Kidney from Control Group. Stain Hematoxylin and Eosin (H\&E). Magnification: 40x (Left) and 100x (Right). VT: Viable Tissue; N: Necrosis Area

The highest BUN level showed by control groups was $67.60 \pm 3.44 \mathrm{mg} / \mathrm{dL}$, followed by LPEE-I (64.40 $\pm 1.14 \mathrm{mg} / \mathrm{dL})$, II $(55.80 \pm 0.84 \mathrm{mg} / \mathrm{dL})$, and III $(52.00$ $\pm 0.71 \mathrm{mg} / \mathrm{dL}$ ) and the lowest BUN level was shown by the standard group that was $42.40 \pm 1.44 \mathrm{mg} / \mathrm{dL}$. Moreover, this study also evaluated the creatinine level and the highest one was shown by the control group that was $0.79 \pm 0.12 \mathrm{mg} / \mathrm{dL}$, followed by LPEE-I, II, and III and the lowest one by the standard group that was 0.32 $\pm 0.01 \mathrm{mg} / \mathrm{dL}$. This study performed a kidney function test, and histology study in all rats' kidneys, and the histology study results were shown as light micrographs described in Figures 1-5. Light micrographs of kidneys in the control group are described in Figure 1.
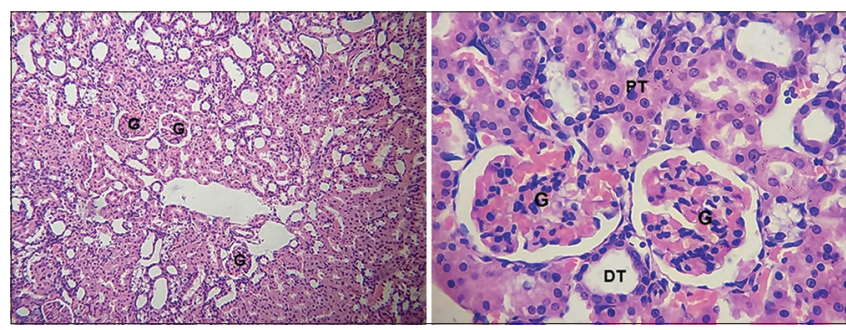

Figure 2: Light micrographs of kidney from Standard group. Stain

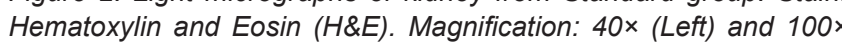
(Right). G: Glomerulus; PT: Proximal tubules; DT: Distal tubules

Based on Figure 1, light micrographs of the kidney from the control group showed an extensive necrotic tissue that was shown as a paler area. This necrotic tissue pressed the viable tissue that became narrower. On the other hand, light micrographs of the

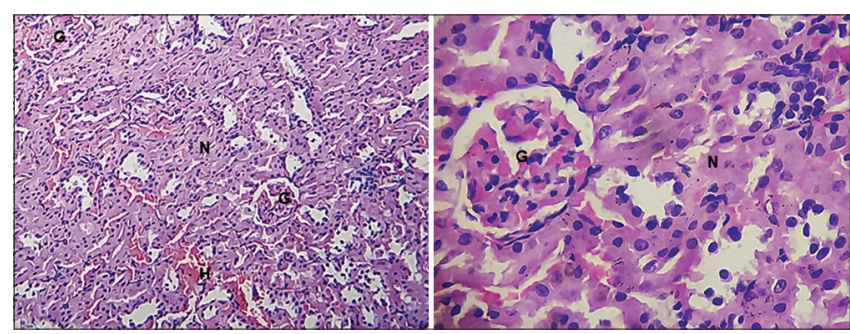

Figure 3: Light micrographs of kidney in the LPEE-I Group. Stain Hematoxylin and Eosin (H\&E). Magnification: 40x (Left) and 100x (Right). G: Glomerulus; H: Hemorrhagic; N: Necrosis area 
kidney from the control group also did not show any glomerular structures; it may be due to the extensive necrotic that also affected the glomerular structure. Moreover, this study also evaluated another kidney from a different group, and light micrographs of the kidney from the standard group are described in Figure 2.

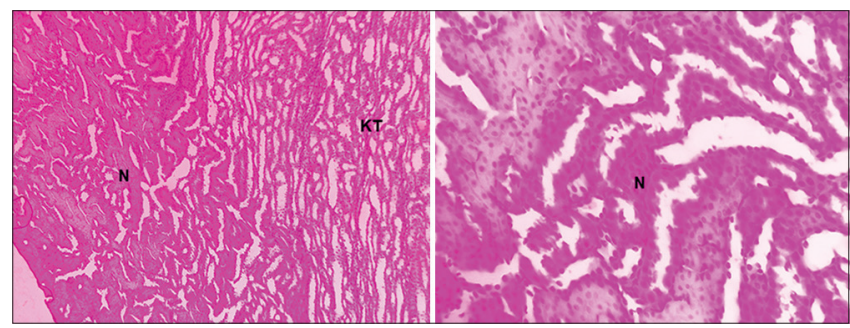

Figure 4: Light micrographs of kidney in the LPS-Il Group. Stain: Hematoxylin and Eosin (H\&E). Magnification: 40x (Left) and 100x (Right). N: Necrotic area; KT: Kidney tubules

Based on Figure 2, light micrographs of kidneys from the standard group showed a better histology feature. There were not necrotic areas in the standard group that looked like the control group. Meanwhile, the higher power field showed intact glomerular structures surrounded by intact kidney tubules such as proximal and distal tubules. Moreover, light micrographs of kidneys from the LPEE-I group are described in Figure 3.

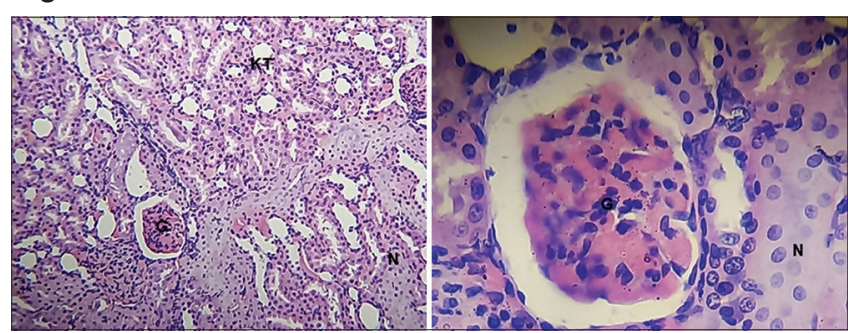

Figure 5: Light micrographs of kidney in the LPEE-III Group. Stain: Haematoxylin and Eosin (H\&E). Magnification: 40x (Left) and 100x (Right). G: Glomerulus; KT: Kidney Tubules; N: Necrosis area

Based on Figure 3, the light micrographs of kidneys in the LPEE-I group also showed a wide necrotic area like the control group. However, this group still owned some intact glomerular structures that differed from the control group. It also indicated a better histology structure than the control group. Moreover, the light micrographs of kidneys in the higher dose group (LPEE-II) are described in Figure 4.

Based on Figure 4, this group also showed a wide necrotic area like in control. However, this necrotic area was not as wide as the control group, and it was observed in the low power field (40x) that there were some intact kidney tubules in half of the low power field. The necrotic area was shown as a paler-colored area at the high-power field. On the other hand, this group did not show any intact glomerular structures. Moreover, the light micrographs of kidneys in the highest dose group (LPEE-III) are described in Figure 5.

Based on Figure 5, the highest dose of lemon pepper extract (LPEE-III) showed a similar light micrograph with the standard group. However, the
LPEE-III group showed a little necrotic area in the low power field, and it was also found in the high power field that was shown as the paler-colored area. Moreover, the LPEE-III group also showed some intact glomerular and kidney tubules like the standard group.

\section{Discussion}

The recent result study answered the purpose of this study. A recent study showed that the lemon pepper ethanol extracts significantly protect the kidney from diabetic nephropathy. It can be seen from the significant decrease in BUN and creatinine level as the kidney function test and the decrease in necrotic area and number of damaged glomerular structures in histology study. Diabetic nephropathy was a microvascular complication from diabetes mellitus. This condition was shown as deterioration of kidney function that leads to a decline in glomerular filtration rate (GFR). The decline of GFR will show an increase in creatinine and blood urea serum level as the early signs of diabetes kidney complication [19].

Based on the recent result study, the BUN and creatinine levels were significantly improved in all LPEE groups. The decreasing average of BUN levels from LPEE-I, II, and III was $4.73 \%, 17.45 \%$, and $23.08 \%$ compared to the control group, respectively. Meanwhile, the decreased average creatinine level from LPEE-I, II, and III was $39.24 \%, 53.16 \%$, and $59.49 \%$ compared to the control group, respectively. None of the previous studies investigated the improvement of kidney function tests from lemon pepper extract against diabetic nephropathy, and the previous study only focused on kidney histology. However, Kaur et al. (2017) reported that diabetic nephropathy was characterized by elevated serum creatinine, BUN, creatinine clearance, and kidney hypertrophy. Moreover, Kaur et al. also reported that the flavonoid content in Dillenia indica L. attenuated the diabetic nephropathy by inhibition of advanced glycation accumulation in streptozotocin-nicotinamide-induced diabetic rats, it was shown by the decrease of BUN and creatinine level from the diabetic rats that received some dosages of Dillenia indica L. extract (100, 200, and $400 \mathrm{mg} / \mathrm{kg} \mathrm{BW}$ ) compared to control group [20]. This previous study was also showed a similar result to a recent study. The previous study showed that the flavonoid contents in Dillenia indica L. may decrease the BUN and creatinine level and the recent study also showed that the LPEE also contented flavonoid and decreased the BUN and creatinine level. Hence, decreasing BUN and creatinine levels by applying lemon pepper methanol extract indicate improved kidney damage caused by diabetic nephropathy.

This study used streptozotocin to induce kidney damage in Wistar rats. Streptozotocin has 
diabetogenic properties by the formation of highly reactive free radicals. These free radicals can damage the protein, membranes, and deoxyribonucleic acid (DNA) of pancreatic cells that disrupt insulin secretion and manifest as a diabetic condition [21]. A prolonged hyperglycemic state increases the workload of the glomerulus and is heavier the filtration process in the glomerulus. The accumulation of glucose in the glomerulus also increases the osmotic pressure, shrinks glomerular cells, and ends as necrosis of the glomerular cells. The damage of glomerular cells passes various substances that should be carried out into efferent arterioles and these substances directly injury the tubules cells [19]. Prolonged tubules injury can end as tubules necrosis. Moreover, streptozotocin also increases oxidative stress due to the accumulation of free radicals in various organs; one of these organs is kidney tissue. These free radicals can cause lipid peroxidation and damage kidney cells [19], [21]

According to the histology study in this study, the application of lemon pepper extract showed an improvement in glomerulus and tubules compared to control groups. The increase of extract dose followed by decreasing the width of the necrotic area in each group. Moreover, the increase of extract dose also increases the number of rescue glomerular structures from the impact of diabetic nephropathy. This histology result study was showed a similar result against the previous study. Worotikan et al. (2017) reported that the lemon pepper methanol extract at a lower dose $(150 \mathrm{mg} / \mathrm{kg}$ BW) induced some improvement against the kidney tissue in alloxan-induced Wistar rats and a higher dose (300 mg/kg BW) enhanced wider improvement area. This improvement was shown to decrease glomerular adhesion, inflamed cells infiltration, and tubular necrosis [7]. This result was similar to the recent study result; the lowest dose of LPEE (500 mg/kg BW) had shown a decrease in tubules necrosis. Meanwhile, the increased dose of LPEE was also followed by the decrease of tubules necrosis shown in Figures $3-5$. In the previous study, the lower dose (150 mg/kg BW) has improved kidney tissue. On the other hand, a recent study required a higher dose (500 $\mathrm{mg} / \mathrm{kg} \mathrm{BW}$ ) to improve kidney tissue. It may be due to the different induction substances used in both studies. The previous study used alloxan as the induction and the recent study used streptozotocin as the induction. It can be seen from the histology of the control group, the previous study by Worotikan et al. (2017) still showed some rescue tubule and glomerular structures. However, the recent study showed the extensive necrosis area that has been substituted by connective tissue and shown in Figure 1.

The kidney protection effect of lemon pepper was due to various phytochemicals such as phenol, saponin, flavonoid, triterpenoid, and alkaloid [11]. These phytochemicals have some pharmacology effects included antioxidant, anti-inflammatory, and anti-diabetic. These phytochemicals were acts as an antioxidant by neutralizing various free radicals due to the presence of phenols compound, namely, 2-methoxy4-vinilfenol with a high $\mathrm{IC}_{50}$ value (66.91 PPM) [8]. On the other hand, lemon pepper extract also can decrease the severity of inflammation by inhibiting the expression of some types of inflammatory biomarkers at the level of protein synthesis (TNF- $\alpha$, COX-2 protein, and MMP9) and genes (TNF- $\alpha$, IL- 6 , iNOS, COX-2, and MMP9) in LPS-induced macrophages by in vitro study [10]. Furthermore, Worotikan et al. (2017) also reported that the lemon pepper extract has anti-diabetic effects and improves the histology of kidney tissue at a dose of $300 \mathrm{mg} / \mathrm{kg} \mathrm{BW}$ [7].

\section{Conclusion}

Overall, the highest dosage of lemon pepper ethanol extract significantly decreased the BUN $(23.08 \%)$ and creatinine (59.49\%) levels. Moreover, the highest extract dose also improved kidney tissue structure by decreasing the width of necrotic area and increasing the number of rescue glomerular structures.

\section{References}

1. Budiharsana MP. Risk differences between elderly men and women toward doctor-diagnosed diabetes mellitus in urban areas in Indonesia: 2013 National Basic Health research data. Kesmas. 2017;12(1):15-21.

2. American Diabetes Association. Standards of Medical Care in Diabetes-2020. New York: American Diabetes Association; 2019.

3. Masruroh E. Hubungan umur dan status gizi dengan kadar gula darah penderita diabetes melitus Tipe II [Relationship between age and nutritional status against blood glucose levels in Type II diabetes mellitus patients]. Journal of Health Sciences. 2018;6(2):153.

4. Soelistijo S, Novida H, Rudijanto A, Soewondo P, Suastika K, Manaf A, et al. Konsesus Pengelolaan Dan Pencegahan Diabetes Melitus Tipe 2 Di Indonesia 2015 [Consensus on Management and Prevention of Type 2 Diabetes Mellitus in Indonesia 2015]. Indonesia: Perkeni; 2015. p. 82.

5. Ningrum AM. Gambaran tingkat pengetahuan penderita diabetes melitus terhadap komplikasi diabetes melitus di kota pontianak [Description of knowledge level in diabetes mellitus patients on complications of diabetes mellitus in Pontianak city]. J MHS PSPD FK Univ Tanjungpura. 2018;3(1):1-13.

6. Powers AC. Diabetes mellitus: Complications. In: Harrison's Endocrinology. $4^{\text {th }}$ ed. New York: Mc Graw Hill; 2017. p. 327-38.

7. Worotikan RV, Tuju EA, Kawuwung F. Analisa efektivitas antidiabetes ekstrak etanol buah andaliman (Zanthoxylum acanthopodium DC) pada histopatologi ginjal tikus putih (Rattus norvergicus) yang diinduksi alloksan [Analysis of anti-diabetic effectiveness of andaliman fruit (Zanthoxylum acanthopodium DC) ethanol extract on alloxan-induced white rat (Rattus norvergicus) kidney histopathology]. Journal of Science, Mathematics and Education. 2017;5(1):29-37. 
8. Winarti W, Simanjuntak P, Syahidin MF. Identifikasi senyawa kimia aktif antioksidan dari ekstrak etil asetat buah andaliman (Zanthoxylum acanthopodium DC) [Identification of antioxidant active chemical compounds from ethyl acetate extract of andaliman fruit (Zanthoxylum acanthopodium DC)]. In: Talenta Conference Series: Tropical Medicine (TM). Medan: Talenta Publisher; 2018. p. 162-6.

9. Sitanggang FM, Duniaji AS, Pratiwi ID. Daya hambat ekstrak buah andaliman (Zanthoxylum acanthopodium DC) dalam etil asetat terhadap pertumbuhan Escherichia coli [Inhibitory ability of lemon pepper fruit (Zanthoxylum acanthopodium DC) ethyl acetate extract on Escherichia coli growth]. Journal of Food Science and Technology. 2019;8(3):257-66.

10. Yanti PT, Nuriasari N, Juliana K. Lemon pepper fruit extract (Zanthoxylum acanthopodium DC.) suppresses the expression of inflammatory mediators in lipopolysaccharideinduced macrophages in vitro. Am J Biochem Biotechnol. 2011;7(4):190-5.

11. Saragih DE, Arsita EV. The phytochemical content of Zanthoxylum acanthopodium and its potential as a medicinal plant in the regions of Toba Samosir and North Tapanuli, North Sumatra. Pros Semin Nas Masy Biodiversitas Indones. 2019;5(1):71-6.

12. Ridho M, Lindarto D. The Effect of Andaliman Fruit Extract to Blood Glucose Levels of Mice with Type 1 Diabetes. In: Adella CA, editor. Stem Cell Oncology. Medan: CRC Press; 2017. p. 95-8.

13. Chiuman L, Ginting CN, Yulizal O, Suhartomi, Chiuman V. Improvement of liver function from lemon pepper fruit ethanol extract in streptozotocin-induced wistar Rats. In: 2021 IEEE International Conference on Health, Instrumentation and Measurement, and Natural Sciences (InHeNce). Medan, Indonesia: IEEE; 2021.
14. Mutia MS, Chiuman L. Efek hepatoprotektif ekstrak etanol Citrus sinensis $\mathrm{L}$. osbeck pada tikus yang diinduksi parasetamol [hepatoprotective effect of Citrus sinensis L. osbeck ethanol extract in paracetamol-induced rats]. Medicine magazine Bandung. 2019;51(4):189-93.

15. Mutia MS. Histology study of liver changes paracetamol-induced wistar rats treated with sunkist (Citrus sinensis L. Osbeck) extract. Am Sci Res J Eng Technol Sci. 2019;59(1):1-7.

16. Mutia MS, Ginting CN, Yulizal O. Sunkist peel ethanol extract ameliorates diabetic nephropathy in streptozotocininduced diabetic wistar rats. Open Access Maced J Med Sci. 2021;9(A):1086-91.

17. Wardhani FM, Chiuman L, Ginting CN, Ginting SF. Role of cystatin-C as serum biomarkers in predicting glomerular function associated with copper-induced acute kidney injury. Medicine magazine Bandung. 2020;52(1):16-21.

18. Ongko NX, Chiuman L, Ginting CN. Effect of white turmeric rhizome extract (Curcuma zedoaria) on testis histology of male wistar rat. Am Sci Res J Eng Technol Sci. 2019;55(1):69-74.

19. Sembiring F, Unitly AJ, Eddy L. Effects of clove syrup therapy on creatinine, urea, and kidney histology of diabetes mellitus rat. J Biothecnol Conserv Wallacea. 2021;1(1):31-41.

20. Kaur N, Kishore L, Singh R. Dillenia indica L. attenuates diabetic nephropathy via inhibition of advanced glycation end products accumulation in STZ-nicotinamide induced diabetic rats. J Tradit Complement Med. 2017;8(1):226-38. https://doi.org/10.1016/j. jtcme.2017.06.004 PMid:29322013

21. Vijayaraj R, Kumaran NS, Swarnakala. In vivo and in vitro models for biological screening of anti-diabetic drugs. Int $\mathrm{J}$ Pharm Sci. 2019;9(2):294-86. 